Prof. B. van de Beek
Professor emeritus
of VU University
Amsterdam and
extraordinary professor
of the University of
Stellenbosch, South
Africa.
E-mail: beekavd@
xs4all.nl

DOI: http://dx.doi. org/10.18820/23099089/ actat.v38i2.9

ISSN 1015-8758 (Print) ISSN 2309-9089 (Online)

Acta Theologica 2018 38(2):145-159

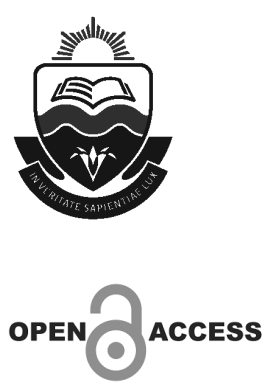

\section{WHERE IS OUR HOME?}

\section{ABSTRACT}

Early Christians considered themselves strangers in the world. This view was deeply rooted in the forgoing Jewish tradition. The Torah begins with human beings who are not at home; they had been driven away from the garden of Eden. The patriarchs dwelled as sojourners in Canaan. Later, Israel ended with the diaspora. According to the New Testament, Christians are strangers even more, because their home is in heaven with Christ. Consequently, they can be at home everywhere, since they are at home nowhere. Therefore, nationalism or striving for an ideal society should be alien to Christians. They only support the well-being of the country in which they live, as far as that is possible in a world where human beings are never really at home - a situation of which Christians are fully aware. It is precisely by this attitude that they contribute most to the well-being of other people.

\section{INTRODUCTION}

Every foreign land is to them as their native country, and every land of their birth as a land of strangers (To Diognetus 5).

This phrase from the early Christian document: To Diognetus, summarizes how Christians saw their position in the world in the first centuries of the Christian era. ${ }^{1}$ At first sight it seems to express an ambiguity. Actually, it is in this very ambiguity that Christians have lived for centuries - even up to the present. On the one hand, Christians are not at home in this world; on the other hand, they

1 The anonymous document To Diognetus might belong to heterodox circles in early Christianity (see Van de Beek 2002). However, as for the content of chapter 5, it displays the common Christian heritage of the first centuries. 
feel very much at home in whatever country they may live. The latter position is often dominant - certainly for Christians today. Even when they criticise the country in which they live, this criticism is intended to make the country a better dwelling place. However, in To Diognetus the word "foreign" is used twice. This makes the phrase more complicated. It does not merely express an ambiguity. Both parts of the sentence are not in opposition, but intrinsically related, according to second century Christianity. This presents a challenge in order to understand how Christians regarded their position in the world, something which is more complicated than a simple ambiguity. This challenge can be an eye opener for current Christians as they reflect on their own position in society. In this article we respond to the challenge presented by the unknown author of To Diognetus.

To Diognetus does not reflect on Christianity as an isolated unity. The author positions Christians in relation to Jews (ch. 3f) and humanity as a whole (ch. 2 and 6). In comparison with the other ways of life, the characteristic identity of Christians becomes clear. With this approach the author shares the common view of early Christian theologians, who also claimed that Christianity is a third kind of humanity, a triton genos (Tertullian, To the Nations I,8). We do not elaborate on this now, but focus on the fact that such comparisons are rooted in the very beginnings of the tradition in which Christianity arose. Jewish thinkers positioned their tradition in the whole of humanity long before To Diognetus. In doing so they borrowed from and reacted to the cultures among which they lived. The relationship between humanity, Jews, and Christians has an historical sequence. Israel and Christianity did not exist from the beginning, but arose as an historical event. However, they also represent fundamentally different approaches to reality. This is apparent in the awareness that Israel is not, at least should not be, like all other peoples, and that Christians are totally different, because they know Christ. Against the background of the historical sequence, this awareness distinguishes three different kinds of human beings (cf. Miskotte 1956; De Kruijf 1981). Within humanity as a whole, Israel is different, and Christians differ from both. Furthermore, Israel and Christians both regard their position as the way that God chose for those whom He elected to be his beloved people.

In this article we first analyse Israel's considered position among the peoples of the world. Subsequently, we survey the self-reflection of early Christians. Finally, we trace its relevance in current public theology. 


\section{HUMANS ARE NEVER AT HOME}

Israel's prophets positioned their nation within the context of all the peoples of the world as expressive of humankind as a whole. They do so explicitly in the first eleven chapters of the book Genesis, which is the beginning of the Torah and the beginning of the Bible. After the introductory chapter in which God is confessed as the creator of the universe, a section follows about the characteristics of this world (Gen 2:4-4:26): it is the account of what heaven and earth produced (Gen. 2:4; the following section begins in $5: 1)$. This account reveals the specific position of humankind in the whole of creation: that humans are never at home. They have lost their homeland in the garden of Eden. Moreover, they are involved in conflicts in which the strong kill their weaker brothers. Consequently, they feel even more uprooted, since they must always live in fear of revenge (4:14). This is the fundamental human condition: never being at home ${ }^{2}$ and incessantly in a deadly contest of fear with victims and perpetrators, who counter the fear of revenge by threatening with greater revenge (4:24).

This is humankind. The story also tells how the leading people tried to overcome this fear: they built a city (4:17). Cain did so, and so did the people of Babylon after the flood (Gen. 11). They wanted a city so powerful that it would not be jeopardized by the revenge of the weak, or even by the wrath of the gods. They built a city, but all their efforts were frustrated, either by a natural disaster such as the flood (Gen. 6f), or by internal conflicts as in Babylon (11:7-9). The feeling of not being at home, and the frustration due to failure to overcome this unrest, that is humanity.

Within this humanity God chooses for the weak: for Abel (nothingness) (4:4), for Enosh, the mortal man (4:26), for Enoch, who was taken from earth in the prime of his life $(5: 23)$, and for Noah, who did not build a city with foundations, but a boat drifting on the waters of chaos (Gen. 6-8).

2 Reflections on this human condition can be traced in classic literature such as Homer's Odyssey and Vergil's Aeneid. Those works have a happy ending with coming home or building a home. They end like Gen. 2-4: finding or building a city as a home. According to Israel's prophets the home for Israel is not the result of human perseverance, but a new beginning and a gift of God.

Modern authors argue that human beings are deficient beings ("Mängelwesen"). See e.g. Gehlen 1974:20, 354; Pannenberg 1983:36-38. Human life is a continuous quest for a ground of being, which it never can obtain from its own nature (Tillich 1964:207). 


\section{ISRAEL}

The Torah tells that God called Abram from this general human condition (Gen. 12:1-3). The Lord will make his offspring a unique people. He promises his children the land of Canaan. They will no longer be an uprooted people, but have a place to stay, the land of rest. They will be a nation of peace and justice.

The Tenach, the Jewish canon, describes this position in three phases. First there is a period of preparation, in which the outlines of the identity of the children of Abraham are drawn. They are different from all other peoples, and exactly therefore they are strangers in this world (Hebr.), specifically in the core land of the cursed nations: the land Canaan (Gen. 12:5-7; 17:8; 23:4; 26:3; 35:27; cf. 9:25-27). ${ }^{3}$ A tomb was the only possession of Abraham's family (Gen. 23:17-20). Moreover, they were strangers in Egypt (Ex. 22:21; 23:9; Lev. 19:34; Deut. 23:7; 26:5; Ps. 105:23), the symbol of power, culture, and prosperity at that time. After their liberation they wandered in the desert for forty years where they learned the will of God for the life in the land they would receive. Among these nations they were strangers, but having received the land, the situation was reversed. There they would no longer be drifters, but have an enduring abode and a holy city with foundations.

The Promised Land will be a new beginning, a new garden of Eden, a land where human beings are at home and do not kill their weaker brothers but treat them justly. There will be no poverty (Deut. 15:4) for the Lord commands care for widows and orphans (Ex. 22:22; Deut. 14:29; $24: 17-21 ; 26: 12 f)$. At home in God's own land - that is how Israel differs from the rest of humankind. Humankind is never at home. It uses its resources to no avail - building a city which ends in destruction. After hundreds of years of preparation the people of Israel had received a home.

The difference between Israel and the nations is not only that they have a home. It is much more: this home is God's home. It is not a place they built themselves, but a gracious gift of the Lord. The Egyptians themselves had to improve the fertility of their land by means of ingenious irrigation systems - Israel received a land made fertile by the rains from heaven (Deut. 11:11). Not only the land but also its gifts are given by the Lord. The land is not their own. So Solomon can declare: we are strangers:

3 The use of these verses for the underpinning of apartheid is an absolute misinterpretation of the text. It is not about black people, but about the people in the land that Israel received from God (see Van de Beek 2017:377). And in Christian theology, also this first layer of interpretation must be reinterpreted from the paradigm of Christ who died on behalf of cursed people. 


\begin{abstract}
Everything we have has come from you, and we give you only what you first gave us! We are here for only a moment, visitors and strangers in the land as our ancestors were before us. Our days on earth are like a passing shadow, gone so soon without a trace (1 Chron. 29:14f).
\end{abstract}

Israel does not cease to be strangers, but the difference with the other peoples is that they have a home: they dwell in the home of the Lord and by obeying his commandments they can also feel at home, where life is good. They can trust and live without the unrest which stirs the nations. Therefore, they can take care of strangers so that they, too, can find rest in Israel. Throughout the Old Testament Israel is exhorted to welcome strangers, to share their prosperity with them and is strictly forbidden to oppress them.

The ideal of the prophets is that the nations will see what happens in Israel and therefore turn to Israel's God (Is. 2:2; Jer. 16:19; Micha 4:1-3; cf. Ps. 86:9). They will prefer such a life above the struggle under their own conditions. The whole earth will become a garden of peace and justice (Zach. 9:9f). Creation will return to its beginnings and the lost paradise will be regained.

However, this is not what happened. The nations did not come to Israel for submission to the glory of Israel's God, but to submit Israel to the glory of their own gods. This is the third phase. Israel no longer has a home but is dispersed among the peoples as a diaspora of strangers. The project of a nation being a home and a blessing for all nations had failed. Consequently, the people who were different, became the strangers. And actually, it was so from the very beginning, for the project could only start with total destruction and genocide, as stated in the book of Joshua. Clearing a place on earth for one nation at the expense of other nations is tantamount to ethnic cleansing.

The cause of the failure of the promises to the nations was not only the unwillingness of the nations, but most of all Israel's own inability to trust the Lord. They could not accept being dependent on the Lord. Instead they claimed the land as their own project, which they had to conserve with ordinary human tools: a king, an army, and religious rituals for prosperity and fertility. Thus, Israel became like all the peoples (1Sam. 8:5, 20) and the Lord dealt with them as with all the peoples. Israel is either a nation of justice and peace, or it is no longer relevant. Since the Israelites did not want to be strangers who are at home in the house of the Lord, they projected their unrest on the other people by treating strangers as enemies (Neh. 13:3; 1 Macc. 3f). For that very reason they became like all nations.

All human beings are homeless. They try to overcome this by building cities. Israel had a homeland, but they lost it, because they did not trust in God. They tried to overcome this by creating a home with external 
religious identity markers: circumcision, the Sabbath, prescribed food, and clothing. While the nations based their identity on power, the Jews based it on rituals. Both turned out to be futile. They did not give rest because they consisted of human striving. It is never enough because it is ever in danger of destruction. There is a competition of power in the world and a competition of piety among the Jews. They can never be at home.

\section{A POLITEUMA IN HEAVEN}

Christianity also claims a new beginning. Paul says explicitly that being in Christ is being a new creation (2 Cor. $5: 17$ ). The core of Christian identity is the unity of believers with Christ. They are in Christ and Christ lives in them (Gal. 2:20). He defines their very identity. He is not just their foundation, their home, but their very being. And He has a home in heaven. He did his work in order to prepare a dwelling for them in his Father's house (John 14:2). Paul elaborated on this most explicitly in his letters. "Our politeuma is in heaven" (Philipp. 3:20). The place of registration of Christians where their true identity is saved is heaven. Because this defines their very being, it must also determine all their actions:

Since then, you have been raised with Christ, set your hearts on things above, where Christ is, seated at the right hand of God. Set your minds on things above, not on earthly things. For you died, and your life is now hidden with Christ in God (Col. 3:1-3).

Christians must be totally different, because they know Christ (Eph. 4:20).

Christians behave differently than pagans and Jews. They do not have to compete with others to maintain their position. They are free, for they have eternal life. Nothing can harm them (Rom 8 38f). They need not rid themselves of individuals who are not useful to them, like the pagans do. They need not distinguish themselves by means of food and clothes like the Jews. They are different, because they are free to love and to serve. To Diognetus describes this eloquently:

Inhabiting Greek as well as barbarian cities, according as the lot of each of them has determined, and following the customs of the natives in respect to clothing, food, and the rest of their ordinary conduct, they display to us their wonderful and confessedly striking method of life. They dwell in their own countries, but simply as sojourners. As citizens, they share in all things with others, and yet endure all things as if foreigners. Every foreign land is to them as their native country, and every land of their birth as a land of strangers. They marry, as do all others; they beget children; but they 
do not destroy their offspring. They have a common table, but not a common bed. They are in the flesh, but they do not live after the flesh. They pass their days on earth, but they are citizens of heaven. They obey the prescribed laws, and at the same time surpass the laws by their lives. They love all men, and are persecuted by all. They are unknown and condemned; they are put to death, and restored to life. They are poor, yet make many rich; they are in lack of all things, and yet abound in all; they are dishonoured, and yet in their very dishonour are glorified. They are evil spoken of, and yet are justified; they are reviled, and bless; they are insulted, and repay the insult with honour; they do good, yet are punished as evil-doers. When punished, they rejoice as if quickened into life (To Diognetus 5).

They do not only behave differently, they are different. They are eschatological new beings, living in Christ. Because they belong to Him, they belong to heaven. Consequently they are strangers on earth. This is an elementary belief in early Christianity (Hebr. 11:3; 2 Petr. 2:11). This conviction has its roots in the Old Testament. We already noticed that Solomon confessed that the Israelites were foreigners in the house of the Lord. And his father David went even deeper: he who really wants to keep God's commandments is a stranger on earth (Ps. 119:19; cf. Ps. 39:13). Similarly, Christ was a stranger from heaven (De Jonge 1977), not as an alien from another planet, but precisely because $\mathrm{He}$ was the only human being who fulfilled the law for true humanity: love for God and love for the neighbour, which justly deems the others more important than oneself (Phil. 2:3). This is divine love and this is Christian love, which has no place on earth. Both pagans and Jews rejected Christ, and both pagans and Jews reject his followers.

Since early Christians believed their home is heaven, they were not interested in political change. They accepted the political system and leadership. They even prayed for the government, not for a radical change to an open and democratic society, but for a peaceful and quiet life (1 Tim. 2:2). Leave things as they are. Christians even thought of the governmentas a divine institution, as Paul argues in Romans 13. This was not about a government with good and just leadership, but about the Roman emperor Claudius.

Early Christians showed a remarkable political disinterest. One can see this as a flight from reality. However, it was rather a deeper understanding of reality. First of all, they were interested in the deepest reality: in God and our being in Him. This took priority over everything else. The core of their life and the focus of their thought were the Eucharist as participation in the eschatological eternal life. Due to this conviction, every country was foreign to them and only of secondary interest. That was basic. 
However, also on the level of this secondary interest, they had a deeper sense of reality than those who chose for political change. The oppression by a dictator was to be preferred to the horror of terrorism and civil war. Christians in the present Middle East wholeheartedly agree with their predecessors of almost two millennia ago. And they did so when the first signs of an Arabic Spring dawned. Having a dictator is hard, but it is to be preferred by far to the hardships of civil war. Be happy if you have a government which at least keeps some stability - a peaceful and quiet life - without many ideals.

The sense of reality goes deeper. Even if the present government should be replaced, the new one will not be essentially better. The same kind of people will return, for human beings are all more or less the same. In this world there will not be an ideal society, only one more or less evil for the time being. Ultimately the empires of this world are like beasts (cf. Dan. 8; Rev. 12f) and they will fight against each other to the very end, until they will be overcome by the last judgement evoked by their own Armageddon, as the victory of God over human pride. Human beings have sought a city with a solid foundation from the very beginning, from the first powerful man Cain, and they will continue to do so until their ultimate project will collapse and the world with it. ${ }^{4}$ Christians know about a city with foundations (Hebr. 11:10), and of the kingship of Christ who is on the throne of God. It is the kingship of the King of the Jews, crucified, and his followers will share his fate, bearing his cross through a world of competing powers.

There is another sense of reality. Christianity is a religion of life. It knows very well about death. It can also deal with death, for it knows of the victory over death in the resurrection of Christ. Therefore, Christians focus on life. Death belongs to the past. Consequently, a Christian will not and cannot kill another human being. They not only reject murder, but any kind of killing (Sider 2012; Van de Beek 2007). Therefore, they reject war and consequently also the army (Tertullian, On the Chaplet; Apostolic Tradition 16,9-11). "We are pacifists", wrote Origen (Commentary on Matthew), and the earliest church law of Rome did not accept a soldier in the church, not even as a catechumen. For the same reason they rejected abortion (Hippolyt, Refutation IX,12). In the Greek and Roman cultures it was customary that babies were not considered as human beings until the father had legally accepted the child. If he did not do so, the baby could be done away with (Goodman 2008:234f). Girls were

4 "The Apocalypse, if it ever happens, is far more likely to be the upshot of technology than the work of the Almighty ... Who needs an angry God to burn up the planet when as mature, self-sufficient human beings we are perfectly capable of doing the job ourselves?" (Eagleton 2009: 133f). 
often not accepted. Christians took pity on these rejected children and cared for them. Christians receive life as a gift of God and this life belongs to Him alone. Early Christian writers as diverse as Origen in Alexandria, Tertullian in Carthage, and Hippolytus in Rome, rejected any killing and any possibility of killing by Christians. Consequently, Christians did not participate in governmental administration (Origen, Against Celsus 8,75), for government implies power and, if needed, violence to enforce the will of the government. It implies defence of its subjects, and therefore police, judges, and an army.

One wonders whether early Christians were unaware that they would be suspect of escapism, and for that reason of leaving others in the hands of the wicked and the evil? If they enjoyed the fruits of stability provided by a government because of its having the sword, why should Christians not take responsibility for it?

Early Christians were very much aware of being blamed for this. The philosopher Celsus challenges them to indeed take on responsibility for politics. Origen answers him that Christians make their own contribution to society. They are a very specific army, not an army with swords, but an army that prays. Prayer contributes more to society than an army (Origen, Against Celsus 8,73-75). In the last instance the army is based on fear; prayer is based on trust. When you approach your enemies with fear, they will overcome you. If you come in trust, they are defenceless. They can take your life, but not your God, who restores the dead to life.

Because Christians know of the resurrection of the dead, they are not afraid to help those who are in the sphere of death. They can help the leper, because they are not afraid of contracting the disease themselves. While in times of disease and pestilence aristocrats and even priests and physicians fled the contaminated cities, early Christians often remained in the cities during such epidemics to care not only for their fellow believers, but also for pagans who were left behind (Kruger 2017: 28).

The others are more important than themselves. They can help the disabled and accept disabled children. As To Diognetus says:

They marry, as do all others; they beget children; but they do not destroy their offspring. They have a common table, but not a common bed.

They help other people to mitigate the troubles of life, but they do not cause trouble in people's lives by breaking the bond of mutual responsibility. Christian life is not a competition about who is best, but a continuous servantship, because we are free from any obligation. 


\section{CHRISTIANITY TODAY}

What does this early Christian heritage mean for the church today? The phrase: "Every foreign land is to them as their native country, and every land of their birth as a land of strangers" could evoke the idea that the church should be an alternative community (cf. Hauerwas \& Willimon 1989: 46; Hauerwas 1995; 2000; Hauerwas \& Willimon 1996). Christians are totally different, a community with its own rules, not the rule of violence, but of love, not the rule of power, but of service. It is a community of people who live according to Pauls' exhortation: "In your relationships with one another, have the same mindset as Christ Jesus" (Philipp. 2:5)

This, however, would imply a separated social group, with its own rules and its own characteristic identity (Van de Beek 2010: 132-137). Such a group should not turn its back on the world, but influence it, in order to change society. Actually, this is more in line with the Old Testament than the New. It is a community which is separated from the world by its own identity, but also tries to spread its influence until the whole world is convinced that this is the best way of life.

The first problem is that the world is not inclined to be convinced. This became clear with Israel. The world has its own rules and characteristic identity. So all that remains is to keep oneself untarnished by the world within an own serious Christian community. Orthodox Judaism drew this conclusion a long time ago. They no longer tried to change the world. They were content with their own closed pious community. Christians may be inclined to do the same, but this would go against their basic confession: that Christ came for the salvation of the world.

A more serious problem is that Christians themselves are not inclined to keep to the rules of such an alternative community. They are averse to pacifism. They too are egoistic. They are just ordinary human beings - as the entire history of the church shows. They were so also in the time of Diognetus. Conflicts pervaded the church throughout her existence, through indifference at times, but most of all through human strife. The disciples of Jesus had two fundamental shortcomings: they argued continuously about who was the most important and they did not understand that being a Christian meant following Christ in bearing the cross. Like his first disciples, so too are his disciples in the twenty-first century. Indeed, an alternative community evokes these shortcomings: who adheres best to the characteristic identity? And how can we safeguard our community against our opponents - from without and from within?

So, an alternative community is no option. 


\section{AT HOME IN ANY COUNTRY}

An alternative community is no option. Diognetus does not plead for it. He not only says "Every land of their birth is to them as a land of strangers" but also "Every foreign land is to them as their native country." It does not even matter in which country Christians live, or to which social group or rank they belong. Their home is in heaven. Consequently, any earthly house is incidental. There is no specific Christian community and no specific Christian nation exists. ${ }^{5}$ The only community Christians share, is the communion with Christ in the Eucharist. They are an eschatological community in Him and in the memorial celebration of his death they are at home. Christians are not at home in a ghetto and they are not at home in a country with a Christian phrase in its constitution. They are at home where they weekly, and if possible even daily, celebrate the Eucharist. For that reason, they can be at home in any country and in any community, wherever they live, whether by birth or otherwise. Christians do not have national interests, they do not exercise power through pressure groups or influence through political affiliations. The present-day interest in public theology is as much at odds with the roots of the Christian tradition as national churches and denominations are.

Does this imply that Christians are not interested in society? Do they not contribute to the well-being of all? If Christians focus on eternal life, the quest for social ethics becomes urgent. If their hearts and minds are in heaven, do they care for human beings on earth? Certainly they do, even more so than any pressure group or alternative community. They celebrate their unity with Christ. They pray - also for the government. Their focus is on Christ in whom they have eternal life and eternal love. Consequently they can give up everything, as Christ did when He, while being God, became human, obedient as a slave, even unto death and execution (Philipp. 2:8). His glory was hidden, and it is hidden in this world. So too, is the glory of the church. She does not make breaking news. She does not launch great projects. Her life is concealed in heaven with Christ. He is not the great example who must be imitated. When reading the Greek text of Philippians 2:5, it must be noted that Paul does not say: "You must do as Christ did." Not even: "Let this mindset be in you as was in Him". He says: "Think and decide (phroneite) in such a way that corresponds with being in Christ." Since you have eternal life and eternal freedom, you can serve your fellow human beings as a slave. The second century writer, Aristides, states about Christians' care for other people:

5 Cf. Tertullianus, To the nations 1,8: Christians are not another nation, but present in all nations, they transcend all nations. 
And whenever one of their poor passes from the world, each one of them according to his ability gives heed to him and carefully sees to his burial. ... And if there is among them any that is poor and needy, and if they have no spare food, they fast two or three days in order to supply to the needy their lack of food (Aristides, Apology, cited by Kruger 2017:28).

This is not only their attitude towards fellow Christians, but to all people, because it is the result of the Spirit of Christ who dwells within them. Certainly, not all Christians displayed and display this attitude. That is, however, not because they are directed to Christ in heaven, but precisely because they are too earthly. If Christians are related to Christ and the eternal life in Him, they display high social ethics. They do so not in conspicuous projects, but following the spirit of love which is in them. They are not even aware of it, as Christ himself says when speaking about the final judgement (Matt. 25:31-46). They serve the Lord in the service of the poor. God's presence is a hidden presence, not only in Christ who was crucified in this world, but also in the Spirit who dwells in the church, which does not make breaking news in this world.

Let the church celebrate her life in Christ in worship and service and the benefit of this worship will be the most profound contribution to society. The answer of Origen to Celsus' challenge is: they offer a service to the well-being of all through prayer:

As we, by our prayers, vanquish all demons who stir up war, and lead to the violation of oaths, and disturb the peace, we in this way are much more helpful to the kings than those who go into the field to fight for them (Origen, Against Celsus 8,73).

Christians are like the soul in the body, says To Diognetus:

What the soul is in the body, Christians are in the world. The soul
is dispersed through all the members of the body, and Christians
are scattered through all the cities of the world. The soul dwells in
the body, yet is not of the body; and Christians dwell in the world,
yet are not of the world. The invisible soul is guarded by the visible
body, and Christians are known indeed to be in the world, but their
godliness remains invisible (To Diognetus 6).

The soul is not visible. One can even deny its existence. The divine life of the church is invisible. One can even deny it. But it is the very life of the world. Without the church the world is a dead body. The presence of Christ makes it alive. Without the celebration of the Eucharist - the presence of God on earth - everything loses its meaning. Christians 
should focus on this reality. It will change their minds and make them free to regard others more important than themselves. Having received eternal life and love, which they cannot lose, they can offer themselves to the poor in the world who lack everything. This makes the difference in a world full of competition, power, claims to rights, racism, and violence. Antiquity was a world of powerful men. "Christianity ... lacks the GrecoRoman ideal of masculinity" (Kruger 2017:35). Consequently, "Christianity offered a more favourable and positive environment for women compared with their position in the broader Greco-Roman world" (Kruger 2017:36f). Human beings are God's creation and equally willed by Him. Human life is his gift, equally for women and men, of any ethnic or social community. The deepest impact of Christian faith is that it is better to lose your life than to take a life. If it is about your life, your possessions are a minor problem. Giving is more blessed than receiving - or even taking. So early Christians suffered along with those in prison and joyfully accepted the confiscation of their property, because they knew that they have better and lasting possessions (Hebr. 10:34).

The parable of the talents (Matt. 25:14-30; Luk. 12:11-27) is a good illustration of the role of Christians in the world. The parable is about the kingdom of God. It is not about the talents that the slaves receive to contribute to its coming. Their lord himself sets off and will receive the kingdom. The slaves do not make any contribution to it. Their only task is to mind the business during the time of his absence. This is the task of Christians in the world until the coming of Christ: they are caretakers keeping things in good order in this world as far as is possible. We will not establish the kingdom of God. It is enough if we keep things in balance and not abuse our position to oppress others or for our own profit. We may not beat our fellow servants or eat and drink with drunkards (Luk. 12:45f). Christians do not have a dream. They do not have a dream about God's kingdom, for this is not a dream, but reality. This they always express in the doxology of the prayer: "For yours is the Kingdom". They also do not have dreams about this world, for the world will not change for the better. They have a sober contribution to society: helping to keep and restore things in balance, without any kind of violence, for in God there is no violence (To Diognetus 7). 


\section{BIBLIGORAPHY}

DE JONGE, M.

1977. Jesus, stranger from heaven and Son of God: Jesus Christ and the Christians in Johannine perspective. Sources for Biblical Studies. Missoula: Scholars Press.

Diognetus, THE LETTER TO.

MPG 2:1167-1186. Translated by Alexander Roberts and James Donaldson. From Ante-Nicene Fathers, Vol. 1. Edited by Alexander Roberts, James Donaldson, and A. Cleveland Coxe. (Buffalo, NY: Christian Literature Publishing Co., 1885.) Revised and edited for New Advent by Kevin Knight. [Online.] Retrieved from http://www.newadvent.org/fathers/0101.htm (2017, 15 December)

EAgLeton, T.

2009. Reason, faith, and revolution. reflections on the God debate. New Haven: Yale University Press.

Gehlen, A.

1974. Der Mensch. Seine Natur und seine Stellung in der Welt. 10. Aufl. Frankfurt am Mein: Athenaion Verlag.

Goodman, M.

2008. Rome and Jerusalem. The clash of ancient civilizations. New York: Vintage Books.

HAUERWAS, S.

1995. In God's Company. The Church as Polis. Notre Dame/London: University of Notre Dame Press.

2000. A better hope. Resources for a church confronting capitalism, democracy, and postmodernity. Grand Rapids: Brazos Press.

HaUerWas, S. \& Willimon, W.H.

1989. Resident aliens. A provocative Christian assessment of culture and ministry for people who know that something is wrong. Nashville: Abingdon Press.

1996. Where resident aliens live. Exercises for Christian practice. Nashville: Abingdon Press.

Hippolytus.

Refutatio omnium haeresium. MPG 16.3:3009-3454.

KRUGER, M.J.

2017. Christianity at the cross roads. How the second century shaped the future of the church. London: SPCK.

KRUIJF, G.G.DE.

1981. Heiden, jood en christen. Een studie over de theologie van K.H. Miskotte. Baarn: Ten Have. 
MisKotTE, K.H.

1956. Als de goden zwijgen. Over de zin van het Oude Testament. Amsterdam: Uitgeversmaatschappij Holland.

Origenes.

Contra Celsum, MPG 11:641-1632.

Commentarius in Mattheum. MPG 13:829-1800.

Pannenberg, W.A. 1983. Anthropologie in theologischer Perspektive. Göttingen: Vandenhoeck und Ruprecht.

SIDER, R.J.

2012. The early church on killing: A comprehensive sourcebook on war, abortion, and capital punishment. Grand Rapids: Baker Academic.

Tertullianus.

Ad Nationes, MPL 1:629-608.

De corona, MPL 2:73-102.

TILLICH, P.

1964. Systematic Theology I. Digswell Place: Nisbet.

Traditio APOSTOLICA

la Tradition Apostolique d'après les anciennes versions. 2e éd., Sources Chrétiennes 11bis. Paris: Cerf.1984.

Van de Beek, A.

2002. Marcionitism in To Diognetus: a plea for Christians at the expense of Jews. NGTT 43:593-605.

2007. No violence in God? No violence in us? In: D. van Keulen, M. Brinkman (eds.), Christian faith and violence 1. Studies in Reformed Theology 10. (Zoetermeer: Meinema), pp.12-27.

2010. Lichaam en Geest van Christus. De theologie van de kerk en de Heilige Geest. Zoetermeer: Meinema.

2017. Mijn Vader, uw Vader. Het spreken over God de Vader. Utrecht: Meinema.

Key words

Christian life

Diognetus

Strangers

Diaspora
Trefwoorde

Christelike lewe

Diognesius

Vreemdelinge

Diaspora 